\title{
Current behavior of sudden cardiac arrest and sudden death
}

\author{
Comportamiento actual del paro cardíaco súbito y muerte súbitos \\ Humberto Rodríguez-Reyes*, Mayela Muñoz-Gutiérrez, and José L. Salas-Pacheco \\ Department of Research, Sociedad Cardiovascular y Arritmias (SOCAyA), Aguascalientes, Mexico
}

\begin{abstract}
Sudden cardiac arrest (SCA) and sudden death (SD) continue to be a global public health problem, although the true incidence is unknown, it is estimated that they are responsible for $30 \%$ of cardiac origin mortality and may represent $20 \%$ of total mortality in adults. Unfortunately, the majority of cases occur in the general population, at the out-of-hospital level, in homes and in people who were not known to have heart disease. Although the majority of SCA victims are considered to be of cardiac origin and more frequent ischemic, it is not possible to rule out other causes only with the clinical diagnosis. Autopsy, histological, and toxicological studies are necessary in all victims of SCA and SD to determine the precise cause of death; when these studies are carried out, causes of non-cardiac origin have been found in up to $40 \%$ of victims. The type of arrhythmia responsible for an episode of SCA and SD has changed over the years, now asystole and pulseless electrical activity are detected more frequently than ventricular fibrillation or pulseless ventricular tachycardia. These and other aspects that we consider important in the current behavior of SCA and SD are analyzed in this article.
\end{abstract}

Key words: Sudden cardiac arrest Sudden death. Asistolia. Electric activity without pulse. Ventricular fibrillation. Pulseless ventricular tachycardia.

\section{Resumen}

El paro cardíaco súbito (PCS) y la muerte súbita (MS) continúan siendo un problema de salud pública mundial; aunque su verdadera incidencia se desconoce, se calcula que producen el 30\% de la mortalidad de origen cardíaco y pueden representar el $20 \%$ de la mortalidad total en los adultos. Desafortunadamente, la mayor parte de los casos se presenta en la población general, de forma extrahospitalaria, en los hogares y en personas que no se conocían portadoras de cardiopatía. Aunque se considera que la mayoría de las víctimas de PCS es de origen cardíaco, y que es más frecuente el isquémico, no es posible descartar otras causas sólo con el diagnóstico clínico. Son necesarios la necropsia y los estudios histológicos y toxicológicos en todas las víctimas de PCS y MS para determinar la causa precisa de la muerte; cuando estos estudios se efectúan se han encontrado causas de origen no cardíaco hasta en $40 \%$ de las personas. El tipo de arritmia causante de un episodio de PCS y MS ha cambiado a través de los años; ahora se detectan con mayor frecuencia asistolia y actividad eléctrica sin pulso (AESP) que la fibrilación ventricular (FV) o la taquicardia ventricular sin pulso (TVSP). Estos y otros aspectos de importancia en el comportamiento actual del PCS y la MS se analizan en este artículo.

Palabras clave: Paro cardíaco súbito. Muerte súbita. Asistolia. Actividad eléctrica sin pulso. Fibrilación ventricular. Taquicardia ventricular sin pulso.

\section{Correspondence:}

*Humberto Rodríguez-Reyes

E-mail: humbertorodriguezr@ hotmail.com
Available online: 04-09-2020

\section{Arch Cardiol Mex (Eng). 2020;90(2):183-189
www.archivoscardiologia.com \\ Arch Cardiol Mex (Eng). 2020;90(2):183-189
www.archivoscardiologia.com} 2604-7063 / @ 2019 Instituto Nacional de Cardiología Ignacio Chávez. Published by Permanyer. This is an open access article under the CC BY-NC-ND license (http://creativecommons.org/licenses/by-nc-nd/4.0/).

Date of reception: 12-03-2019

Date of acceptance: 10-12-2019

DOI: 10.24875/ACME.M20000114 


\section{Introduction}

In adults, sudden cardiac arrest (SCA) is one of the main signs of heart disease, with symptomatic or asymptomatic ischemic heart disease are considered to be the cause of most cases ${ }^{1-3}$. SCA occurs when the heart suddenly and unexpectedly stops pumping blood; the victim loses the state of alertness, has no signs of circulation and only gasps; without treatment, this abnormality leads to sudden death (SD). Some individuals with SD may have previous symptoms, such as chest pain, dyspnea, syncope, pre-syncope, or seizures, but often they go unnoticed $^{4}$. SD is also suspected in people who had been seen alive within a period not longer than $24 \mathrm{~h}$ and then were found lifeless in the absence of an obvious cause of death, such as those cases identified at dawn without an observer ${ }^{5,6}$. It is a public health problem worldwide $^{7}$; SD is estimated to account for $30 \%$ of cardiac-origin mortality, and for $20 \%$ of deaths in adults ${ }^{8-10}$. The true incidence of SCA and SD is unknown, and there are variations according to the studied population; in China, Europe, and USA, 41, 86, and 155 cases have been reported per 100,000 population/year, respectively ${ }^{11-13}$. In the population younger than 35 years, an incidence of $1-3$ cases/100,000 population/year is considered ${ }^{14}$, and at 75 years of age, 800 cases $/ 100,000$ population/ year $^{13,15}$. In 2015, 17.7 million of deaths associated with cardiovascular diseases were reported in the world ${ }^{16}$; $30 \%$ of these are likely to be due to SCA and SD, which can represent up to 5.31 million cases/year (Table 1).

\section{Causes according to age groups}

The causes vary with regard to age groups; in people older than 25 years, symptomatic or asymptomatic coronary artery disease is the main cause $9,10,14$. From 20 to $40 \%$ of cases can be secondary to cardiomyopathies due to systemic arterial hypertension, obesity, diabetes, alcohol, as well as to idiopathic, valvular, congenital, infiltrative, non-compacted myocardial fibrosis, or heart failure ${ }^{6,8,10,13}$. Slightly more than $50 \%$ of adults with SCA and SD have no previous diagnosis of structural heart disease, only a high prevalence of cardiovascular risk factors, especially systemic arterial hypertension, diabetes mellitus, sedentary lifestyle, smoking, obesity, and dyslipidemia ${ }^{4-6}$. In few cases, SD is consecutive to primary arrhythmic disease in adults ${ }^{5,6}$. In those younger than 25 years, the main causes are hypertrophic cardiomyopathy, congenital anomalies of the coronary arteries, arrhythmogenic cardiomyopathy, and primary arrhythmic disease, such as Wolff-Parkinson-White syndrome, long
Table 1. SD in adults worldwide, calculated causes, and survival

\begin{tabular}{|l|c|}
\hline Cardiovascular deaths worldwide/year (2015) & 17.7 million \\
\hline SCA and SD/year (30\% of cardiovascular mortality) & 5.31 million \\
\hline $\begin{array}{l}\text { Causes } \\
\text { Ischemic heart disease }\end{array}$ & $60-80 \%$ \\
$\begin{array}{l}\text { Cardiomyopathies (hypertrophic, dilated, valvular, } \\
\text { etc.) }\end{array}$ & $20-40 \%$ \\
\hline $\begin{array}{l}\text { Primary arrhythmic disease } \\
\text { Detected arrhythmias }\end{array}$ & $1-2 \%$ \\
\hline $\begin{array}{l}\text { Asystole } \\
\text { PEA }\end{array}$ & \\
\hline VF/PVT & $40-50 \%$ \\
\hline $\begin{array}{l}\text { Out-of-hospital cases } \\
\text { At home } \\
\text { In public areas }\end{array}$ & $30 \%$ \\
\hline $\begin{array}{l}\text { Without observer } \\
\text { Overall survival }\end{array}$ & $20 \%$ \\
\hline
\end{tabular}

PEA: pulseless electrical activity; VF: ventricular fibrillation; PVT: pulseless ventricular tachycardia.

QT syndrome, Brugada syndrome, short QT syndrome, catecholaminergic polymorphic ventricular tachycardia, and idiopathic ventricular fibrillation (VF) ${ }^{14,17}$. Unfortunately, the exact cause of death is unknown in most cases and only undergo verification by anatomopathological, histological, or toxicological examination; the diagnosis of cardiac-origin SD (CSD) is almost always a clinical approach, which overestimates the causes and the incidence ${ }^{18,19}$. A recent study of 525 people with CSD, with a mean age of 62.8 years and with $69 \%$ of males, identified non-cardiac-origin causes in $40 \%$ of cases (34\%, drug overdose; $60 \%$, opiates; $14 \%$, neurological causes; $11 \%$, infectious causes; $9 \%$ pulmonary embolism; and 7\%, gastrointestinal bleeding $)^{18}$. Another study of 1039 CSD victims with a mean age of 32 years ( $66 \%$ males), identified that $28 \%$ of cases were due to non-cardiac-origin causes $(40 \%$, pulmonary; $20 \%$, infectious; $18 \%$, cerebrovascular; and $8 \%$ other neurological diseases) ${ }^{19}$. Recently, the American Heart Association (AHA), the American College of Cardiology and the Heart Rhythm Society have recommended the performance necropsy studies in all SCA and SD victims, to confirm the diagnosis and find the exact causes of death ${ }^{20}$.

\section{Causal arrhythmias}

Over the years, the type of arrhythmias causative of a SD episode has changed; previously, VF and pulseless ventricular tachycardia (PVT) were recognized as the 


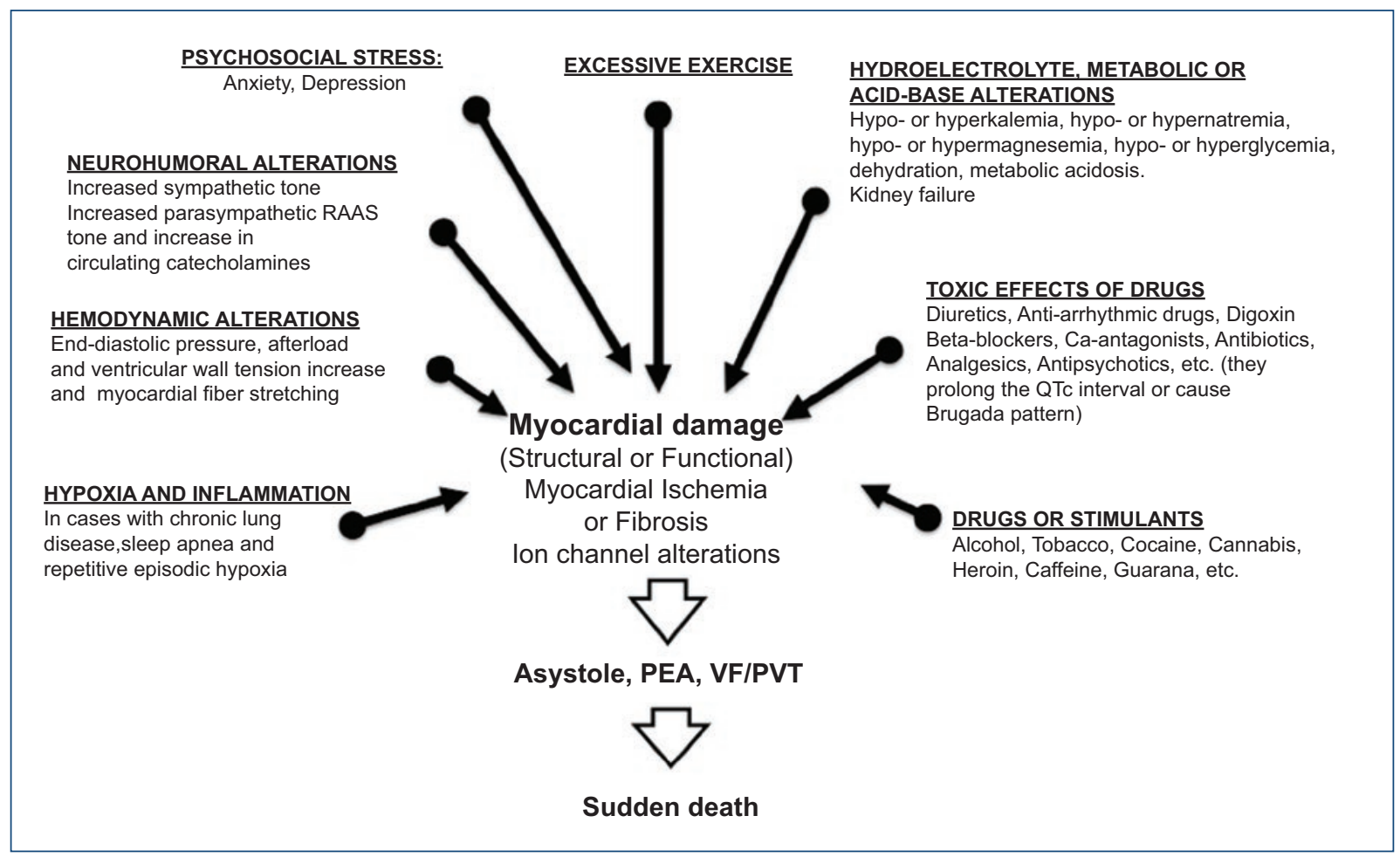

Figure 1. Substrates and activators of malignant arrhythmias, sudden cardiac arrest, and sudden death.

main origins, but currently, asystole, and pulseless electrical activity (PEA) are recorded more frequently ${ }^{10,13,20,21}$. VF and PVT appear to be the most common causes of SCA and SD in cases that occur away from home and in those related to physical activity ${ }^{13}$. In the general population, asystole has been found in $40-50 \%$, PEA in $30 \%$ and VF/PTV in $20 \%$ of cases $^{20}$.

\section{Malignant arrhythmia substrates}

For malignant arrhythmias to occur, the participation of substrates and activators acting on the heart is required. The most important substrates are myocardial ischemia, myocardial fibrosis, and ion channel abnormal-

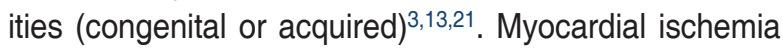
favors the dispersion of refractory periods and the presence of activity in ventricular myocardial cells ${ }^{3,13}$; myocardial fibrosis gives rise to the development of ventricular reentry circuits $^{22}$, and ion channel abnormalities, to ventricular depolarization and repolarization alterations ${ }^{23}$.

\section{Malignant arrhythmia activators}

In all SCA and SD victims, the participation of substances, drugs, or metabolic alterations that work as activators and that can be the origin of the episode should be ruled out. Malignant arrhythmia triggering factors that may be involved (Fig. 1) are various: (a) increased activity of the sympathetic and parasympathetic nervous system, of the renin-angiotensin system and increase in the number of circulating catecholamines ${ }^{6}$; (b) hemodynamic factors such as end-diastolic pressure, afterload, and left ventricle parietal stress elevation ${ }^{7}$; (c) hydroelectrolytic alterations such as hyponatremia, hypokalemia, hypocalcemia or hypomagnesemia ${ }^{6}$; (d) metabolic disturbances such as dehydration, acidosis, hyperglycemia, or hypoglycemia²; (e) hypoxia ${ }^{24}$; (f) iatrogenic factors secondary to the use of drugs such as diuretics, inotropics, vasodilators, anti-arrhythmic agents, or drugs that prolong the QT interval or favor the presence of Brugada pattern, such as some antibiotics, antipsychotics, or analgesics ${ }^{25}$; (g) drugs and addictive substances such as alcohol, tobacco, cocaine, cannabis, heroin, or LSD ${ }^{26}$; (h) energy drinks with high content of sugar, caffeine, guarana, and other stimulating substances $^{27}$; (i) excessive exercise ${ }^{28}$, and (j) psychosocial stress, specially anxiety, and depression ${ }^{3}$.

\section{Clinical characteristics and risk group}

Based on SCA and SD victims clinical characteristics, the population is classified into three groups, as 
Table 2. SCA and SD victims clinical characteristics. Group Characteristics

Group 1 General population with risk factors for ischemic heart disease such as:

Systemic arterial hypertension, diabetes mellitus, smoking, obesity, dyslipidemia, and sedentary lifestyle

Group 2 Structural heart disease

Ischemic, hypertrophic, dilated, valvular, congenital, infiltrative heart disease, non-compacted, arrhythmogenic cardiomyopathy, heart failure, abnormalities in the origin or trajectory of coronary arteries, and congenital heart diseases.

Kidney failure, chronic pulmonary disease, or sleep apnea

Primary arrhythmogenic disease

Wolff-Parkinson-White, long $\mathrm{QT}$, and Brugada syndromes, malignant early repolarization, catecholaminergic polymorphic VT (CPVT), and short OT syndrome

Group 3 Subjects recovered from SCA or with a history of VF, $V T$, or syncope secondary to ventricular arrhythmias Idiopathic VT or VF

Any patient in these groups is considered to be at higher risk and having a family history of SD should be a reason for more exhaustive examination.

shown in table 2: group I, population with risk factors for ischemic heart disease, but without a diagnosis of the previous heart disease ${ }^{5,6,9,10}$; Group II, carriers of some structural heart disease $e^{1-3}$, chronic lung disease $^{29}$, sleep apnea ${ }^{30}$ or kidney failure ${ }^{31}$; and Group III, survivors of a SCA episode or arrhythmic death highrisk carriers ${ }^{32}$. Symptomatic or asymptomatic myocardial ischemia is the most important risk factor for developing SCA and SD in adults ${ }^{1-3}$. In patients diagnosed with ischemic heart disease, those of the male gender, who are smokers and have persistent STsegment elevation with frequent ventricular extra-systoles are at increased risk of SCA and $\mathrm{SD}^{33}$, as it occurs in patients in whom increased myocardial ischemia, myocardial fibrosis, or total occlusion of the coronary artery related to a heart attack have been detected $^{6}$. Heart failure (HF) patients with left ventricular ejection fraction (LVEF) lower than 30\% have a high risk of dying from SCA and SD ${ }^{34}$. LVEF as the only arrhythmic-origin SD predictor is insufficient; the Seattle classification helps recognize arrhythmic death highrisk carriers who can benefit from an automated implantable cardioverter defibrillator (AICD) ${ }^{35}$; figure 2 shows the clinical characteristics related to higher risk of SCA and SD and that confer higher possibility of response to the implantation of an AICD in patients with $\mathrm{HF}$ of ischemic or non-ischemic origin. Recently, the detection of ventricular myocardial fibrosis by magnetic

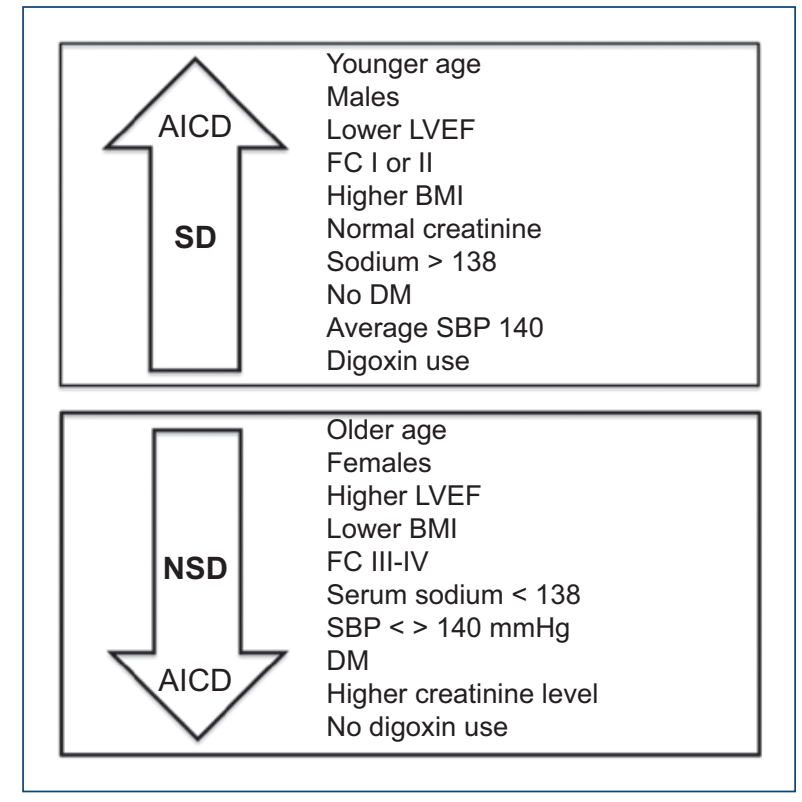

Figure 2. Clinical characteristics according to the scale of Seattle and their relationship with the mode of death and response to an automated implantable cardioverter defibrillator in patients with heart failure of ischemic or non-ischemic origin (modified from Levy et al. ${ }^{33}$ ).

resonance imaging in patients with $\mathrm{HF}$ of ischemic or non-ischemic origin has been shown to be a more efficient predictor to identify patients at high risk of arrhythmic death who may benefit from the use of an $A I C D^{36}$. Patients with chronic obstructive pulmonary disease have 2-3 times higher risk for developing cardiovascular diseases, arrhythmias and death ${ }^{37}$. The risk of SCA and SD is higher in those with chronic lung disease and frequent exacerbations of hypoxia episodes $^{29}$. In individuals with obstructive sleep apnea syndrome, the presence of frequent episodes of apnea, hypopnea, and nocturnal hypoxia is associated with a higher incidence of SCA and $\mathrm{SD}^{38}$. Kidney damage increases the risk of SD, with up to $22 \%$ of deaths in these patients being due to SCA and $\mathrm{SD}^{39}$. Albuminuria is an early marker of kidney damage and an independent predictor of SCA and SD, which in addition increases its predictive value when linked to a glomerular filtration rate lower than $60 \mathrm{~mL} / \mathrm{min} / 1.73 \mathrm{~m}^{2,40}$.

\section{Symptoms before an episode of SCA and SD}

There is evidence that, in children and adults with SCA, the previous symptoms are common ${ }^{41,42}$. In children, $26-33 \%$ of victims had some type of symptom, 
Table 3. Sequence of steps for the care of the SCA victim in the community; manual-only CPR and use of public-access AED

1. Recognize the victim in cardiac arrest (suddenly collapses, does not respond, does not breathe, is pale or livid).

2. Give notice to local emergency number (in Mexico, 911), request an AED, put the call on speaker for assistance.

3. Start compressions at the center of the chest, between the two nipples from 100 to $120 \mathrm{x}^{\prime}, 5$ to $6-\mathrm{cm}$ deep in adults and 4 to $5 . \mathrm{cm}$ in children, until AED or assistance arrival.

4. Quickly use the AED:

- Open the AED and follow the instructions

- Place the patches as directed, use pediatric patches in children younger than 8 years, do not touch the victim while the AED analyzes

- If applying a discharge is necessary, the AED will indicate so

- Warn: "Clear, nobody touch the victim", before applying the discharge

- Apply the discharge on the button that blinks

5. Restart compressions until the patient recovers, assistance arrives, or AED indicates

and in $45 \%$ of cases, symptoms had occurred even 40 days before the episode; the most common symptoms were chest pain, seizures of unknown causes, dyspnea, and syncope ${ }^{41}$. In adults, up to $50 \%$ of victims had previous symptoms and men suffered chest pain more often, while women experienced dyspnea ${ }^{42}$. Subjects with SCA who experienced symptoms and requested help or sought medical care before the event, significantly improved survival in comparison with those who did not ask for help (32\% vs. $6 \%)^{42}$.

\section{SCA treatment in the community}

Specific treatment of a SCA victim includes cardiopulmonary resuscitation (CPR) maneuvers and the use of an automated external defibrillator (AED); table 3 shows the steps to follow for the care of SCA in the community. The earlier CPR is applied and AED used, the higher the survival likelihood of those affected by $\mathrm{SCA}^{43}$. In the cases of VF and PVT, which occur more frequently away from home ${ }^{13}$, early defibrillation highly significantly improves the survival rates (Fig. 3); when CPR is started and defibrillation is carried out within the first 2 min after SCA occurrence, survival rates of up to $71 \%$ can be achieved, with good neurological recovery. Within the $1^{\text {st }} \mathrm{min}$, ventricular defibrillation success is higher than $90 \%$, and it drops by $7-10 \% /$ min without CPR. The latter prolongs the time window for the possibility to perform successful defibrillation. The AHA CPR guidelines ${ }^{44}$, as well as studies in the general population, emphasize the importance for both the

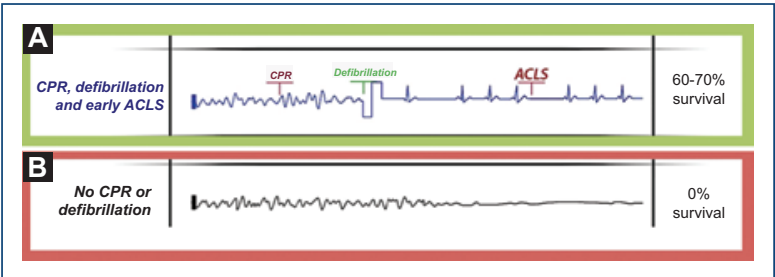

Figure 3. A: Cardiopulmonary resuscitation (CPR), defibrillation, and early advanced cardiovascular life support (ACLS) after a sudden cardiac arrest episode, with significant improvement in the likelihood of survival. B: Without CPR or early care, no victim survival.

general public and health personnel to be trained and have the knowledge to perform high quality CPR and use an $\mathrm{AED}^{45}$. Exclusively manual compressions and the use of public access AED have been shown to be highly effective for improving SCA victims survival in the community ${ }^{46}$. There are important limitations for the treatment of people with SCA occurring at home, where most cases are recorded; the most commonly detected rhythms are asystole and PEA; the possibilities of early detection and treatment are reduced and treatment success is much lower than that achieved in cases with VF and PVT ${ }^{21}$. In Mexico, some cases of SCA victims survival have been reported, when the survival chain is properly implemented ${ }^{47}$, and the creation of a comprehensive care system for individuals with SCA is strongly recommended ${ }^{48}$.

\section{Conclusions}

SCA and SD are a global public health problem. Unfortunately, almost all cases occur in the general population, in out-of-hospital settings, at home and in people who were unaware of being heart disease bearers. True incidence and prevalence are unknown. Carrying out anatomopathological, histological and toxicological studies in all people with SD is advisable to find the exact cause of death, which will help the provision of better prevention measures. At present, the most commonly identified arrhythmias are asystole and PEA. Symptoms before a SCA occur in up to $33 \%$ of children and $50 \%$ of adults; when victims seek medical attention before experiencing the episode, survival is significantly improved. High-quality CPR and AED use are SCA initial treatment; in the cases of VF and PVT, AED early use substantially improves survival; health personnel and the general population should know and apply these measures. Favoring manual-only CPR and 
AED use programs in the community to reduce SCA mortality is advisable. Further research and prevention measures applied to the general population are needed to reduce the incidence of SCA and SD.

\section{Acknowledgment}

The authors express their gratitude to their patients and coworkers in the cardiology field, who are the reason for this review.

\section{Funding}

The authors received no sponsoring to carry out this document.

\section{Conflicts of interest}

The authors declare that they have no conflicts of interest.

\section{Ethical disclosures}

Protection of people and animals. The authors declare that no experiments were performed on humans or animals for this investigation.

Confidentiality of data. The authors declare that they have followed the protocols of their work center on the publication of patient data.

Right to privacy and informed consent. The authors declare that no patient data appear in this article.

\section{References}

1. Katritsis D, Gersh B, Camm J. A clinical perspective on sudden cardiac death. Arrhythmia Electrophysiology Review 2016;5(3):177-182.

2. Benjamin E, Blaha M, Chiuve S, Cushman M, Das S, Deo R, et al. Heart disease and stroke statistics-2017 update: a report from the American Heart Association. Circulation 2017:135:e146-e603.

3. Hayashi M, Shimizu W, Albert CM. The spectrum of epidemiology underlying sudden cardiac death. Circulation Res. 2015;116:1887-1906.

4. Fishman GI, Chungh SS, DiMarco JP, Albert CM, Anderson ME. Sudden cardiac death prediction and prevention: report from a National Heart Lung, and Blood Institute and Heart Rhythm Society Workshop. Circulation 2010;122:2335-2348.

5. Kong H, Peterson E, Fonarow G, Sanders G, Yancy C, Russo A, et al. Addressing disparities in sudden cardiac arrest care and the underutilization of effective therapies. Am Heart J 2010;160:605-618.e1.

6. Rodríguez-Reyes $\mathrm{H}$, Muñoz M, Márquez MF, Pozas G, Asensio E, Ortiz $\mathrm{F}$, et al. Muerte súbita cardíaca. Estratificación de riesgo, prevención y tratamiento. Sudden cardiac death. Risk stratification, prevention and treatment. Arch Cardiol Mex. 2015;85(4):329-336.

7. Wellens HJ, Schwartz PJ, Lindemans FW, Buxton A, Goldberger J, Hohnloser S, et al. Risk stratification for sudden cardiac death: current status and challenges for the future. European Heart Journal 2014;35:1642-1651.

8. Chugh SS, Reinier K, Teodorescu C, Evanado A, Kehr E, Samara M, et al. Epidemiology of sudden cardiac death: clinical and research implications. Prog Cardiovasc Dis. 2008:51:213-228.

9. Fox C, Evans J, Larson M, Kannel W, Levy D. Temporal trends in coronary heart disease mortality and sudden cardiac death from 1950 to 1999. The Framingham Hearth Study. Circulation 2004;110:522-527.
10. Ni H, Coady S, Rosamond W, Folsom A, Chambless L. Trends from 1987 to 2004 in sudden death due to coronary heart disease: The Atheroesclerosis Risk in Communities (ARIC) study. American Heart Journal 2009;157:46-52.

11. Hua W, Zhang LF, Wu YF, Liu XQ, Guo DS. Incidence of sudden cardiac death in China: analysis of 4 regional populations. J Am Coll Cardiol. 2009;54;1110-1118.

12. Gräsner JT, Lefering R, Koster RW, Masterson S, Böttiger BW, Herlitz J, et al. EuReCa ONE- 27 Nations, ONE Europe, ONE Registry. A prospective one month analysis of out-of-hospital cardiac arrest outcomes in 27 countries in Europe. Resuscitation 2016:105:188-195.

13. Mozaffarian D, Benjamin EJ, Go AS, Arnett DK, Blaha MJ, Cushman M, et al. Heart disease and stroke statistics-2016 update. A report from the American Heart Association. Circulation 2016;133:e38-e360.

14. Meyer L, Stubbs B, Fahrenbruch C, Maeda Ch, Harmon K, Eisenberg M, et al. Incidence, causes, and survival trends from cardiovascular-related sudden cardiac arrest in children and young adults 0 to 35 years of age. A 30-year review. Circulation 2012:126:1363-1372.

15. Galea S, Blaney S, Nandi A, Silverman R, Vlahov D, Foltin G, et al. Explaining racial disparities in incidence of and survival from out-of-hospital cardiac arrest. Am J Epidemiol. 2007;166:534-543.

16. $\mathrm{WHO} /$ Cardiovascular diseases (CVDs). Fact sheet $\mathrm{N}^{\circ} 317$, Updated January 2015. www. who.int/mediacentre/factsheets/fs317/en/\#

17. Winkel BG, Risgaard B, Sadjadieh G, Bundgaard H, Haunso S, Tfelt-Hansen. Sudden cardiac death in children (1-18 years): symptoms and causes of death in a nationalwide setting. Eur Heart J. 2014;35:868-875.

18. Tseng ZH, Olgin JE, Vittinghoff E, Ursell PC, Kim AC, Sporer K, et al. Prospective countywide surveillance and autopsy characterizacion of sudden cardiac death. POST SCD Study. Circulation 2018;137:2689-2700.

19. Risgaard B, Lynge TH, Wissenberg M, Jabbari R, Glinge Ch, Gislason GH, et al. Risk factors and causes of sudden noncardiac death: a nationwide cohort study in Denmark. Heart Rhythm 2015;12:968-974.

20. Hara M, Hayashi K, Hikoso S, Sakata Y, Kitamura T. Different impacts of time from collapse to first cardiopulmonary resuscitation on outcomes after witnessed out-of-hospital cardiac arrest in adults. Circ Cardiovasc Qual Outomes 2015;8:277-284.

21. Myerburg RJ, Halperin H, Egan DA, Boineau R, Chugh SS, Gillis AM, et al. Pulseless electrical activity. Definition, causes, mechanisms, management, and research priorities for the next decade: report from a National Heart, Lung, and Blood Institute Workshop. Circulation 2013; 128:2532-2541.

22. Yap S-Chi, Sakhi R, Theuns DA, Yaser YE, Bhagwandien RE, Diletti R, et al. Increased risk of ventricular arrhythmias in survivor of out-of-hospital cardiac arrest with chronic total coronary occlusion. Heart Rhythm 2018;15:124-129.

23. Hyltén-Cavvallius L, lepsen EW, Christiansen M, Graff C, Linneberg A, Pederse $\mathrm{O}$, et al. Glucose ingestion causes cardiac repolarization disturbances in type 1 long QT syndrome patients and healthy subjects. Heart Rhythm 2017;14:1165-1170.

24. Gami AS, Olson EJ, Shen WK, Wright RS, Ballman KV, Hodge DO, et al Obstructive sleep apnea and the risk of sudden cardiac death. A longitudinal study of 10,701 adults. J Am Coll Cardiol. 2013;62:610-616.

25. Kisgaard B, Winkel BG, Jabbari R, Lynge TH, Wissenberg M, Glinge C, et al. Sudden cardiac death. Pharmacotherapy and proarrhythmic drugs: a nationwide cohort study in Denmark. J Am Coll Cardiol. EP 2017;3:473- 48.

26. Bébarová $M$, Horáková $Z$, Kula $R$. Addictive drugs, arrhythmias, and cardiac inward rectifiers. Europace 2017;19:346-355.

27. Enríquez A, Frankel DS. Arrhytmogenic effects of energy drinks. J Cardiovascular Electrophysiol. 2017;28:711-717

28. Emery MS, Kovacs RJ. Sudden cardiac death in athletes. J Am Coll Cardiol. HF 2018;6:30-40.

29. Lahousse L, Niemeijer MN, van de Berg ME, Rijnbeek PR, Joos GF, Hofman $A$, et al. Chronic obstructive pulmonary disease and sudden cardiac death: the Rotterdam study. Eutopean Heart Journal 2015;36:1754-1761.

30. Gami AS, Olson EJ, Shen WK, Wright RS, Ballman KV, Hodge DO, et al. Obstructive sleep apnea and the risk of sudden cardiac death: a longitudinal study of 10,701 adults. J Am Coll Cardiol. 2013;62:610-616.

31. Wang AY, Lam CW, Chan IH, Wang M, Lui SF, Sanderson JE, et al. Sudden cardiac death in end-stage renal disease patients. A 5-year prospective analysis. Hypertension 2010:56:210-216.

32. Al-Khatib SM, Stevenson WG, Ackerman MJ, Bryant WJ, Callans DJ, Curtis AB, et al. 2017 AHA/ACC/HRS Guidelines for Management of Patients With Ventricular Arrhythmias and the Prevention of Sudden Cardiac Death. J Am Coll Cardiol. DOI 10.1016/j.jacc.2017.10.054.

33. Every N, Hallstrom A, McDonald K. Risk of sudden versus non-sudden cardiac death in patients with coronary artery disease. Am Heart J. 2002:144:390-396.

34. Levy W, Mozaffarian D, Linker D. The Seattle heart failure model: prediction of survival in heart failure. Circulation 2006;113:1424-1433.

35. Levy WC, Li Y, Redd SD, Zile MR, Shadman R, Dardas T, et al. Does the implantable cardioverter-defibrillator benefit vary with the estimated proportional risk of sudden death in heart failure patients? J Am Coll Cardiol EP. 2017:3:291-298. 
36. Acosta J, Fernández-Armenta J, Borràs R, Anguera I, Bisbal F, Martí-Almoar J, et al. Scar characterization to predict life-threatening arrhythmic events and sudden cardiac death in patients with cardiac resynchronization therapy. The GAUDI-CRT Study. J Am Coll Cardiol Img. 2018;11:561-572.

37. Konecny T, Somers V. Sudden cardiac death and chronic obstructive pulmonary disease. Evidence, mechanisms, and therapeutic implications. JACC Clinical Electrophysiology 2015;5:388-389.

38. Moubarak G, Bouzeman A, de Geyer d'Orth T, Bouleti C, Beuzelin C, Cazeau S. Variability in obstructive sleep apnea: analysis of pacemaker-detected respiratory disturbances. Heart Rhythm 2017; 14:359-364

39. Wang AY, Lam CW, Chan IH, Wang M, Lui SF, Sanderson JE, et al. Sudden cardiac death in end-stage renal disease patients. A 5-year prospective analysis. Hypertension 2010;56:210-216.

40. Deo R, Khodneva YA, Shlipak MG, Soliman EZ, Judd OM, McClellan, et al. Albuminuria, kidney function, and sudden cardiac death: findings from the Reasons for Geographic and Racial Differences in Stroke (REGARDS) study. Heart Rhythm 2017;14:65-71.

41. Winkel BG, Risgaard B, Sadjadieh G, Bundgaard H, Haunso S, Tfelt-Hansen J. Sudden cardiac death in children (1-18 years): symptoms and causes of death in a nationwide setting. European Heart Journal 2014;35: 868-875).

42. Marijon E, Uy-Evanado A, Dumas F, Karam N, Reinier K, C Teodorescu, et al. Warning symptoms are associated with survival from sudden cardiac arrest. Ann Intern Med. 2016;164:23-29.
43. Olasveenger TM, de Caen AL, Mancini ME, Maconochie IK, Aickin R 2017 International Consensus on Cardiopulmonar Resuscitation and Emergency Cardiovascular Care Science with Treatment Reccomendations Summary. Resuscitation 2017;121:201-214.

44. Kleinman ME, Brennan EE, Goldberge ZD, Swor RA, Terry M, Bobrow BJ, et al. Part 5: Adult Basic Life Support and Cardiopulmonary Resuscitation Quality. 2015 American Heart Association Guidelines Update for Cardiopulmonary Resuscitation and Emergency Cardiovascular Care. Circulation 2015;132(suppl. 2):S414-S435.

45. Kragholm K, Wissenberg M, Mortensen RN, Hansen SM, Hansen CM, Thorsteinsson $\mathrm{K}$, et al. Bystander effort and 1-year outcomes in out-of-hospital cardiac arrest. N Engl J Med. 2017;376:1737-47.

46. Iwami T, Kitamura T, Kawamura T, Mitamura H, Nagao K, Takayama M, et al. Chest compression-only cardiopulmonary resuscitation for out-of-hospital cardiac arrest with public-access defibrillation. A Nationwide Cohort Study. Circulation 2012;126:2844-2851.

47. Fraga-Sastrías JM, Aguilera-Campos A, Barinagarrementería-Aldatz F, Ortiz-Mondragón C, Asensio-Lafuente E. Informe de 3 casos de reanimación extrahospitalaria en la ciudad de Querétaro. Importancia de un sistema integral de atención de emergencias médicas. Arch Cardiol Mex. 2014;84(2):79-83.

48. Rodríguez-Díez G. Importancia de un sistema de atención integral en la recuperación del paro cardio-respiratorio. Importance of an emergency medical care in the recovery of cardiac arrest. Arch Cardiol Mex. 2014;84(2):84-85. 